Інноватика у вихованні. Випуск 11. Том 1. 2020.

УДК 811.111: 378.016 (07)

DOI: $\underline{10.35619 / \text { iiu.v1i11.230 }}$

Гронь Лариса

кандидат педагогічних наук, доцент, доцент кафедри методики викладання іноземних мов Рівненського державного гуманітарного університету, м. Рівне, Україна ORCID: 0000-0002-8115-9798 e-mail: larisa.gron@gmail.com

\title{
АКТИВІЗАЦІЯ УСНОЇ КОМУНІКАТИВНОЇ ДІЯЛЬНОСТІ СТУДЕНТІВ МОВНИХ ФАКУЛЬТЕТІВ ЗАКЛАДІВ ВИЩОЇ ОСВІТИ
}

Анотація. Стаття присвячена проблемі активізації усної комунікативної діяльності студентів мовних факультетів закладів вищої освіти. У роботі наведено загальну характеристику технології проєктного навчання як одного із важливих інноваційних методів активізації іншомовної комунікативної підготовки майбутніх учителів іноземної мови та розглянуто шляхи іiі реалізації у системі навчання іноземних мов у вищій школі; проаналізовано ознаки основних типів навчальних проєктів, методичні етапи роботи за проєктною технологією (етап планування, аналітичний етап, етап узагальнення інформації, етап презентації, оцінювання); наведені чинники, що впливають на ефективність управління самостійною роботою за допомогою проєктної технології. Зазначається, що метод проєкту стимулює активне іншомовне спілкування та самостійну продуктивну діяльність студентів, посилює мотивацію до навчання, що сприяє підвищенню рівня практичного володіння іноземною мовою в цілому та створює максимально сприятливі умови для розкриття їх творчих здібностей. У процесі проєктного навчання у студентів розвивається потреба у самостійному набутті знань у процесі вирішення практичних проблем, уміння дослідницької роботи та критичного мислення.

Ключові слова: усна комунікативна діяльність, проєктна технологія, проєктне навчання, проєкт, типи проєктів, шляхи реалізації проєктного навчання, методичні етапи роботи над проєктом.

Постановка проблеми. В умовах інтенсивного оновлення української освітньої системи висуваються нові вимоги до якості іншомовної освіти у вищій школі. Реалізація Болонського процесу, входження України у світову освітню спільноту призвели до активізації міжкультурних зв'язків і помітно підвищили значущість іноземної мови для фахівців різного профілю.

Головною метою навчання іноземних мов на сучасному етапі на мовних факультетах 3ВО $є$ розвиток у студентів здатності «висловлюватись вільно і спонтанно, не відчуваючи браку мовних засобів для вираження думок; ефективно i гнучко використовувати іноземну мову в різноманітних ситуаціях соціального, навчально-академічного та професійного спілкування» (Ніколаєва, Соловей, Головач та ін., 2001, с. 2), тобто випускник повинен не тільки оволодіти знаннями, уміннями і навичками, а й стратегіями адекватного їх використання для досягнення сформульованих перед ним комунікативних завдань.

Високі вимоги до рівня сформованості іншомовної комунікативної компетенції майбутніх фахівців, зокрема, в усному мовленні, спонукають до пошуку нових форм, методів та способів активізації усної комунікативної діяльності студентів,

(C) Гронь Л., 2020 
які б інтенсифікували процес навчання іноземних мов. Важлива роль у формуванні іншомовної комунікативної компетенції студентів та створенні максимально сприятливих умов для розкриття їх творчих здібностей належить проєктній технології.

Аналіз останніх досліджень і публікацій. Проблема використання проєктної технології у практиці викладання іноземних мов знаходиться у сфері інтересів багатьох вітчизняних і зарубіжних науковців: $\mathcal{C}$. Арнітопуло, Є. Борисова, М. Бухаркіна, Н. Душкова, О. Кіршова, О. Пометун, С. Полат, В. Титова, G. Beckett та P. Miller, D. Fried-Booth, S. Haines та ін.

Мета статті - розглянути шляхи активізації усної комунікативної діяльності студентів мовних факультетів вищих закладів освіти засобами проєктної технології.

Виклад основного матеріалу дослідження. Метод проєкту як освітня технологія виник ще на початку минулого століття. Засновниками цього методу вважаються американські вчені Дьюі та Кілпатрик, які пропонували будувати навчання на активній основі, через практичну діяльність, орієнтуючись на особисту зацікавленість учня і практичну потребу у застосуванні отриманих знань. Сьогодні проєктні технології успішно розвиваються і набувають все більшої популярності за рахунок раціонального поєднання набутих теоретичних знань i ïх практичного використання для вирішення конкретних практичних проблем та завдань.

У методиці викладання іноземних мов термін «проєкт» тлумачиться сучасними науковцями по-різному. Проєкт визначається як комунікативно-пізнавальна діяльність, що створює умови для спільної творчої роботи студентів і моделює їхню (науково-дослідницьку) фахову діяльність, під час якої студенти реалізують власні можливості планування, виконання та оформлення певного професійно спрямованого проєкту засобами усного або писемного іншомовленнєвого спілкування (Тітова, 2001); як система комунікативних вправ, що передбачає самостійну творчу іншомовну діяльність учнів/студентів 3 розв'язання певної проблеми, результатом якої є виокремлений кінцевий продукт (Арванітопуло, 2006 та Кіршова, 2008); як творча навчально-пізнавальна іншомовна комунікативна діяльність, проблемна за формою пред'явлення навчального матеріалу, практична за способом його використання, інтелектуально навантажена за змістом i самостійна за характером здобуття знань, навичок та вмінь (Устименко, 2016); як комплексна інтегративна дослідницька діяльність, яка передбачає взаємопов'язане навчання всіх видів іншомовної мовленнєвої діяльності під час поетапного виконання учнями/студентами різних завдань у ході досягнення попередньо визначеної ними мети і сприяє ефективному формуванню всіх компонентів іншомовної комунікативної компетентності (Beckett та Miller, 2006, Fried-Booth, 2002).

Є. Полат (2008) та Н. Пахомова (2005) під проєктною технологією розуміють комплексну методику використання низки різноманітних рефлексивних, пошукових, проблемних, дослідницьких, наукових методів та інтерактивних прийомів (рольова гра, «мозковий штурм», навчання у співробітництві, дискусія тощо). Незважаючи на різне тлумачення поняття «проєкт», спільною $є$ його основна мета - формування у студентів іншомовної комунікативної компетенції (мовленнєвої, лінгвістичної, соціокультурної тощо) та чітка зорієнтованість на створення спільного кінцевого продукту (проєкту), творчого за своєю сутністю.

3 точки зору процесу навчання проєкт є навчальною діяльністю, який включає дослідження i вирішення певної актуальної проблеми i спрямований на узагальнення та закріплення вивченої навчальної теми. У процесі проєктного 
навчання (project-based learning) зміщуються акценти на самостійність та комунікативну активність студентів, розвиток їх креативності. Студенти самостійно оволодівають знаннями 3 різних джерел інформації у процесі вирішення практичних завдань та проблем, які потребують інтеграції знань із різних предметних галузей (у групі чи індивідуально); оволодівають мовленнєвими вміннями, працюючи в різних групах; розвивають дослідницькі вміння та критичне мислення. У процесі активної взаємодії викладача зі студентами, роль його у процесі реалізації проєктного навчання змінюється. Викладач виступає в ролі координатора активної комунікативної та пізнавальної діяльності студентів, рівноправного партнера та компетентного консультанта, професійні вміння якого спрямовані не стільки на контроль знань і вмінь студентів, а здебільшого на розвиток їх потреби у самостійному набутті знань та діагностиці їх діяльності. Це дозволяє викладачу вчасно надати кваліфіковану допомогу і зняти труднощі у пізнанні та використанні набутих знань та вмінь на практиці. Роль складна i вимагає від викладача високого рівня професійної майстерності.

У педагогіці вирізняють різні типи навчальних проєктів. Найбільш повну загальнодидактичну типологію проєктів запропоновано С. Полат (2000), яка розрізняє проєкти: а) за домінуючим методом і видом діяльності: дослідницькі, творчі, пригодницькі, ігрові, інформаційні, практико-орієнтовані проєкти; б) за характером координації: з прямою координацією, з прихованою координацією; в) за характером контактів: внутрішні, регіональні, міжнародні; г) за кількістю учасників: індивідуальні, парні, групові; д) за тривалістю проведення: короткочасні, середньої тривалості (1-2 місяці), довготривалі (до року); є) за предметом і змістом: у межах однієї галузі знань, міждисциплінарні. Наведена класифікація $є$ універсальною і може використовуватись у процесі викладання будь-якої навчальної дисципліни, у тому числі і для навчання іноземних мов.

Зарубіжні методисти (Beckett та Miller, 2006, Fried-Booth, 2002) виокремлюють три групи проєктів для навчання іноземних мов: груповий проєкт, в якому дослідження проводиться всією групою, але кожен студент вивчає певний аспект iз загальної проблеми; міні-дослідження, під час реалізації якого проводиться індивідуальне соціологічне опитування з використанням анкетування та інтерв'ю; проєкт на основі роботи з літературою, який включає вибіркове читання на тему, яка найбільше цікавить студента і підходить до індивідуальної роботи. Останній тип вважається найпростішим для практичного використання i тому дуже популярний. Однак такі проєкти в основному придатні для навчання іноземної мови для спеціальних цілей (Foreign Language for Specific Purposes). 3 іншого боку, проєкт на основі роботи 3 літературою та міні-дослідження можна розглядати як різновид групового проєкту, що $\epsilon$ надзвичайно важливим для активізації іншомовної мовленнєвої активності студентів.

Проєктам, призначеним для навчання іноземної мови, притаманні як загальні для всіх їх типів характеристики, так і відмінні риси, серед яких домінуючими є: 1) використання іноземної мови в ситуаціях, максимально наближених до умов реального спілкування для створення в освітньому процесі мовного середовища; 2) акцент на самостійній іншомовній комунікативній діяльності (індивідуальній, парній або груповій); 3 ) вибір актуальної цікавої теми, яка безпосередньо пов'язана 3 умовами, в яких реалізується проєкт; 4) відбір мовного матеріалу та видів завдань згідно теми і мети проєкту; 5) презентація проєкту з використанням наочності.

Ефективність управління самостійною роботою студентів за допомогою проєктної технології залежить від низки чинників: предметного змісту проєкту, характеру пізнавальної діяльності студентів, співвідношення видів мовленнєвої 
діяльності, джерела інформації, тривалості та місця виконання проєкту, організаційних форм виконання, ступеня керівництва з боку викладача, кінцевого продукту та практичної значущості його результатів.

Аналіз шляхів активізації усної комунікативної діяльності студентів мовних факультетів ЗВО засобами проєктної технології засвідчив, що інтеграція методу проєкту у навчальний процес може здійснюватись: а) шляхом виконання творчих і дослідницьких завдань у межах навчального курсу, що вивчається; б) шляхом використання проєктної технології як альтернативного способу організації навчального курсу (пошук джерел та відбір інформації, вивчення необхідних мовних одиниць, представлення результатів у вигляді брошури, відеофільму, театральної вистави тощо); в) в межах самостійної (аудиторної та позааудиторної) роботи студентів (підготовка телекомунікаційних проєктів, конкурсів, виставок, творчих вечорів, концертів, вікторин, звітних конференцій тощо). Групові та індивідуальні проєкти, які органічно інтегровані у традиційну систему навчання, дозволяють використовувати матеріал навчального курсу для організації самостійної аудиторної роботи студентів. Однак проєктне навчання в рамках самостійної позааудиторної роботи на мовних факультетах 3 ВО повинно бути орієнтоване, головним чином, на використання набутих знань та сформованих комунікативних умінь студентів, оскільки в таких умовах складно ставити спеціальні навчальні цілі і підготовка таких проєктів займає багато часу.

Робота за проєктною технологією реалізується у декілька етапів: етап планування (пошуковий етап), аналітичний етап, етап узагальнення інформації, етап презентації, оцінка проєкту. На етапі планування здійснюється колективне обговорення проблеми і визначається тема проєкту, яка ділиться на підтеми. Викладач ретельно продумує комунікативні ситуації навчальної діяльності для кожного студента, які вибирають підтеми згідно своїх інтересів, потім обговорюється структура проєкту і складається приблизний план роботи. На цьому ж етапі доцільно визначити терміни виконання проєкту. Аналітичний етап включає збір інформації, іiі аналіз і обробку. Студенти працюють в групах, обговорюють проміжні результати, викладач коментує роботу студентів і коректує мовленнєві помилки. Після цього обов'язково необхідно провести аналіз та узагальнення зібраної інформації і координацію дій різних груп. Під час обговорення теми проєкту перед студентами виникає необхідність самостійного вибору аргументів для власних висловлювань, використання відповідних мовних та мовленнєвих засобів, що активізує розвиток їх іншомовної комунікативної компетенції. Етап презентації (демонстрації проєкту) - кульмінаційна точка роботи над проєктом. На цьому етапі студенти осмислюють здобуту інформацію, систематизують і готують підсумкове представлення результатів своєї роботи у вигляді усних повідомлень, рефератів, малюнків, графіків, схем, радіопередач тощо. Етап оцінки проєкту включає в себе не тільки оцінювання рівня сформованості іншомовної комунікативної компетенції, а й загальну оцінку проєкту щодо теми, смислового контенту, кінцевого результату, участі окремих студентів в організації проєкту і т. iн.

Висновки і перспективи подальших розвідок. Систематичне використання проєктної технології у системі навчання на мовних факультетах ЗВО сприяє активізації усної комунікативної діяльності та розширенню мовних знань студентів, посилює мотивацію до навчання, дозволяє реалізувати ефективну взаємодію усіх учасників освітнього процесу у різних організаційних формах навчальної діяльності, забезпечує процес індивідуалізації навчання, створює мовленнєве середовище, вчить працювати в команді тощо. Подальшу розробку цієї 
проблеми ми вбачаємо в аналізі та уточненні специфіки роботи над окремими типами проєктів, які б забезпечували ефективне формування комунікативних умінь студентів.

\section{СПИСОК ВИКОРИСТАНИХ ДЖЕРЕЛ}

Ніколаєва, С., Соловей, М., Головач, Ю. та ін. (2001). Програма з англійської мови для університетів, інститутів (п'ятирічний курс навчання): Проект. Київ. держ. лінгв. ун-т та ін. 245 с.

Тітова, В. (2000). Комплексне навчання іншомовленнєвої діяльності на базі проектної методики та модульно-рейтингової системи у вищому навчальному закладі. Іноземні мови. 1. с. 38-41.

Арванітопуло, Е. (2006). Проектна методика навчання англійської мови на старшому ступені лічею. Кандидат педагогічних наук. Київський національний лінгвістичний університет. 289 с.

Кіршова, О. (2006). Метод проектів як засіб реалізації цілей професійної підготовки магістрантів мовних навчальних закладів. Вісник КНЛУ: Серія «Педагогіка та психологія». 10. с. 231-237.

Устименко, О. (2016). Типологія проектів у навчанні іноземних мов. Молодий вчений. 2. с. 347-352.

Beckett, G. and Miller, P. (2006). Project-based second and foreign language education: past, present, and future. Greenwich, CT: Information Age Publishing. 286 p.

Fried-Booth, D. (2002). Project work. Oxford: Oxford University Press. 136 p.

Полат, Е. (2000). Метод проектов на уроках иностранного языка. Иностранные языки в школе. 2, 3. с. 17-19, 23-24.

Пахомова, Н. (2005). Метод учебного проекта в образовательном учреждении: [пособие для учителей и студ. пед. вузов]. 3-е изд., испр. и доп. Москва: АРКТИ. $112 \mathrm{c}$.

\section{REFERENCES}

Nikolaieva, S., Solovei, M., Holovach, Yu. ta in. (2001). Prohrama z anhliiskoi movy dlia universytetiv, instytutiv (piatyrichnyi kurs navchannia) [Curriculum for English Language Development in Universities and Institutes] : Proekt. Kyiv. derzh. linhv. un-t ta in. 245 s. (in Ukrainian).

Titova, V. (2000). Kompleksne navchannia inshomovlennievoi diialnosti na bazi proektnoi metodyky ta modulno-reitynhovoi systemy u vyshchomu navchalnomu zakladi [Comprehensive teaching foreign language speech activity on the basis of project method and module rating system at higher education institutions] . Inozemni movy. 1. s. 38-41. (in Ukrainian).

Arvanitopulo, E. (2006). Proektna metodyka navchannia anhliiskoi movy na starshomu stupeni litseiu [Project Method of Teaching English at Senior Teaching Stage of Lyceum]. . Kandydat pedahohichnykh nauk. Kyivskyi natsionalnyi linhvistychnyi universytet. 289 s. (in Ukrainian).

Kirshova, O. (2006). Metod proektiv yak zasib realizatsii tsilei profesiinoi pidhotovky mahistrantiv movnykh navchalnykh zakladiv [Project Method as a Means of Realizing Professional Training Goals of Magister Students of Language Training Institutions]. Visnyk KNLU: Seriia “Pedahohika ta psykholohiia”. 10. s. 231-237. (in Ukrainian).

Ustymenko, O. (2016). Typolohiia proektiv u navchanni inozemnykh mov [Typology of Projects for Foreign Language Teaching]. Molodyj vchenyj. 2. s. 347-352. (in Ukrainian). 
Beckett, G. and Miller, P. (2006). Project-based second and foreign language education: past, present, and future. Greenwich, CT: Information Age Publishing. 286 p.

Friend-Booth, D. (2002). Project work. Oxford: Oxford University Press. 136 p.

Polat, E. (2000). Metod proektov na urokakh inostrannogo yazyka [Project Method at Foreign Language Lessons]. Inostrannye yazyki v shkole. 2, 3. s. 17-19, 23-24. (in Russian).

Pakhomova, N. (2005). Metod uchebnogo proekta v obrazovatelnom uchrezhdenii: [posobie dlya uchitelei i stud. ped. vuzov] [Training Project Method at Education Institution]. 3-e izd., ispr. i dop. Moskva: ARKTI. 112 s. (in Russian).

\title{
INCREASING ORAL COMMUNICATIVE ACTIVITY OF FOREIGN LANGUAGE DEPARTMENT STUDENTS AT HIGHER EDUCATION INSTITUTIONS
}

\author{
Larysa Gron \\ $\mathrm{PhD}$ in Pedagogy, Associate Professor, \\ Associate Professor at Foreign Language Teaching Methodology Department, \\ Rivne State University for the Humanities, \\ Rivne, Ukraine \\ ORCID: 0000-0002-8115-9798 \\ e-mail: larisa.gron@gmail.com
}

\begin{abstract}
The article deals with the problem of increasing oral communicative activity of foreign language department students at higher education institutions by means of project technology. The main objective of the work is to analyze how this method can be used effectively in order to raise the level of foreign language proficiency and create the conditions of encouraging students' communicative competence development for practical mastery of a foreign language which includes the main components: speech competence (the ability to communicate in all forms of speech activity); linguistic competence (language acquisition relating to the topic as an important basis for speaking skills); socio-cultural competence (the development of knowledge about the social and cultural specificity of a second language).

In the work the essence of project technology as one of the important innovative method to increase foreign language communicative skills of future specialists is specified. The features of the main existing project types and methodological stages of working at project (planning, analytical stage, synthesizing information, presentation, assessment) have been analyzed. The ways of project-based learning application in the system of teaching foreign language students of higher education institutions have been suggested, the factors which influence on the effectiveness of conducting independent work by means of project have been considered.

Project method also develops students' critically thinking ability, the ability to extract information from a variety of sources, serves as a crucial motivation factor for gaining new knowledge, enables students to realize their own interest in the area of project theme or the research article, allows to individualize the process of studies as a whole.

Keywords: oral communicative activity, project technology, project-based learning, project, types of project, ways of project-based learning application, methodological stages of working at project.
\end{abstract}

Стаття надійшла до редакиії 28.02.2020 p. 